\title{
Screening Nutritional Status of Hospitalized Patients with Nutritional Risk Screening 2002 and Subjective Global Assessment Tools
}

\section{Hastanede Yatan Hastaların Beslenme Durumlarının Nutrisyonel Risk Skoru 2002 ve Subjektif Global Değerlendirme ile Taranması}

\author{
@-Hazal Aydın', @Neşe Kaya² \\ 'Erciyes University, Institute of Health Science, Department of Nutrition and Dietetics, Kayseri, Turkey \\ ${ }^{2}$ Nuh Naci Yazgan University, Faculty of Health Science, Department of Nutrition and Dietetics, Kayseri, Turkey
}

\begin{abstract}
Aim: The assessment of the nutritional status of hospitalized patients is important to detect individuals who are under malnourishment risk and malnutrition-related conditions. The present study aimed to screen the nutritional status of hospitalized patients with Nutritional Risk Screening 2002 (NRS-2002) and Subjective Global Assessment (SGA) and to compare the results of two screening methods in predicting malnutrition.
\end{abstract}

Material and Method: NRS-2002 and SGA were administered to 134 noncritical service patients within the first days of hospital admission. Tool performance in predicting malnutrition and the association with length of hospital stay (LOS) were analyzed.

Results: $22.4 \%(n=30)$ of the patients were at nutritional risk when screened with NRS-2002; when screened with SGA, 35.8\% $(n=48)$ of the patients were found to be malnourished ( $p=0.015$ ). The hospital LOS (day) of malnourished patients and non-malnourished patients according to NRS-2002 were similar. However, according to SGA, the hospital LOS of malnourished patients was longer than non-malnourished patients $(17.90 \pm 16.93$ vs $10.79 \pm 11.23)$ $(p=0.004)$. In both screening tools, most of the malnourished patients were overweight or obese (the total overweight and obese patients rate $70 \%$ and $75 \%$ according to NRS-2002 and SGA; respectively). Factors associated with malnutrition were only age and hospital LOS $(p<0.05)$.

Conclusion: Considering current criteria for nutritional risk, NRS-2002, as an objective and remarkably powerful tool, seems to provide a better yield for an objective assessment. Besides this, adding subjective parameters to the assessment by applying SGA could increase the capability of detecting the nutrition risk of hospitalized patients for a comprehensive nutritional assessment.

Keywords: Malnutrition, nutritional assessment, nutritional risk screening 2002, subjective global assessment.
Öz

Giriş: Hastanede yatan hastaların beslenme durumlarının değerlendirilmesi, malnütrisyon riski altında olan hastaların ve malnutrisyonla ilişkili diğer durumların tespit edilmesi için önemlidir. Çalışmada, hastanede yatan hastaların beslenme durumlarının Nutrisyonel Risk Skoru 2002 (NRS-2002) ve Subjektif Global Değerlendirme (SGD) tarama araçları ile taranması ve malnütrisyonun belirlenmesinde iki tarama yönteminin sonuçlarının karşılaştırı ması amaçlanmıştır.

Gereç ve Yöntem: NRS-2002 ve SGD, hastaneye kabulün ilk günlerinde 134 kritik olmayan servis hastasına uygulanmıştır. Malnütrisyonun tespitinde tarama aracının etkinliği ve hastanede kalış süresi ile ilişkisi analiz edilmiştir.

Bulgular: NRS-2002 ile tarandığında hastaların \%22,4'ü $(n=30)$ beslenme riski altında olduğu, SGA ile tarama yapıldığında hastaların \%35,8'inin ( $n=48$ ) malnütrisyonlu olduğu saptanmıştır $(p=0,015)$. NRS-2002'ye göre yetersiz beslenen hastaların ve yetersiz beslenen hastaların hastanede kalış süreleri (gün) benzerdi. Ancak SGD taramasına göre malnütrisyonlu hastaların hastanede kalma

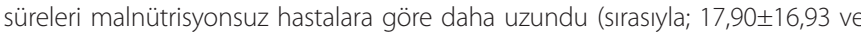
$10,79 \pm 11,23)(p=0,004)$. Her iki tarama aracında da yetersiz beslenen hastaların çoğu aşıı kilolu veya obezdi (toplam aşıı kilolu ve obez hastalar NRS-2002 ve SGD'ya göre sırasıyla; \%70 ve \%75). Malnütrisyon ile ilişkili bulunan faktörler sadece yaş ve hastanede kalış süresiydi $(p<0,05)$

Sonuç: NRS-2002, beslenme riski için mevcut kriterler göz önüne alındığında, son derece güçlü bir araç olarak, nesnel bir değerlendirme için iyi bir verim sağlamaktadır. Bunun yanı sıra, SGD uygulanarak değerlendirmeye subjektif parametrelerin eklenmesi, kapsamlı bir beslenme değerlendirmesi için hastanede yatan hastaların beslenme riskini tespit etme kabiliyetini artırabilir.

Anahtar Kelimeler: Malnutrisyon, beslenme durumunun değerlendirilmesi, nutrisyonel risk skoru 2002 (NRS-2002) ve subjektif global değerlendirme (SGD)

Corresponding (IIletişim): Neşe Kaya, Nuh Naci Yazgan University, Faculty of Health Science, Department of Nutrition and Dietetics, Kayseri, Turkey

E-mail (E-posta): dyt_nese@hotmail.com

Received (Geliş Tarihi): 29.07.2021Ａccepted (Kabul Tarihi): 27.08.2021 


\section{INTRODUCTION}

Malnutrition is an important health problem among patients of all healthcare settings around the world. Disease-related malnutrition is more common in malign disease and chronic diseases (cardiovascular disease, respiratory disease, liver disease, and renal disease) and is associated with higher hospital admission rates, increased length of stay in hospital, mortality and morbidity. ${ }^{[1,2]}$

Hospitalization is also a factor leading to malnutrition due to poor feeding procedures and insufficient intakes of macro and micronutrients. The assessment of the nutritional status of hospitalized patients is important to detect individuals who are under malnourishment risk and malnutrition-related conditions. The American Society for Parenteral and Enteral Nutrition (ASPEN) recommends a nutritional screening for all patients at the beginning of the hospitalization. ${ }^{[3]}$ In guidelines published by ASPEN, it is stated that a nutrition screening should be a component of the initial evaluation of all patients in all care settings (hospital, home) and that the screen should incorporate objective data such as height, weight, weight change, primary diagnosis, and presence of comorbidities. ${ }^{[4]}$ Applying screening tools is accepted as an effective method for nutritional screening. European Society for Parenteral and Enteral Nutrition (ESPEN) recommends Nutritional Risk Screening (NRS) 2002 to consider the nutrition risk of hospitalized patients. ${ }^{[5]}$ The NRS 2002 is a remarkably powerful nutritional screening tool: it is rapid, easy to administer, and does not require highly trained health care professionals. The Subjective Global Assessment (SGA) is a simple and effective tool to assess nutritional status of hospitalized patients by subjective assement that evaluates abnormalities in food intake, gastrointestinal symptoms, functional capacity, diseases related to nutritional requirements and body composition. SGA is a diagnostic tool which determines the presence of a problem in the nutritional status of patients. ${ }^{[6]}$ It was reported that no single parameter was effective to determine malnutrition and the multitude of factors that influence nutritional status in all patients. ${ }^{[7]}$ To overcome the limitations of a single indicator, it has been recommended that more than two indicators of nutrition status be used to detect malnutrition in hospitalized patients. The objective and subjective parameters should be considered together for a comprehensive nutritional assessment. ${ }^{[8]}$ The Academy of Nutrition and Dietetics recommends that added to a nutritional screening by tool, receive patients appropriate nutritional monitoring and evaluation by health care professionals to avoid false negative or positive results on nutritional risk of patients. ${ }^{[6]}$ The capability of detecting nutrition risk may increase by this comprehensive assessment containing subjective parameters.

The present study aimed to access the nutritional status of hospitalized patients screening with two different tools, NRS 2002 and SGA, which are commonly used in clinics.
Additionally to compare the results of two screening methods in predicting malnutrition of hospitalized patients and to observe their association with body mass index (BMI) and length of hospital stay (LOS).

\section{MATERIAL AND METHOD}

\section{Participants}

The study was conducted with 134 adult patients (male/ female: 59/75) who were hospitalized in the clinics (hematology, neurology, gastroenterology, nephrology, endocrine, pulmonary disease and cardiology) of Malatya Training and Research Hospital Hospital between January 1 and August 30, 2016.

The sample size was calculated as the minimum of 88 patients based on the primary outcome variable: the detection of a $5 \%$ difference between the nutritional status and NRS 2002 and SGA tools and statistical power of $95 \%$.

The exclusion criteria included: patients were (i) $<18$ years old, (ii) hospitalized due to surgical operation, (iii) pregnant women, (iv) breastfeeding women, (v) bed-dependent, (vi) suffered an advanced disease that required palliative care.

The study was conducted in accordance with the Declaration of Helsinki Principles. Ethical approval Clinical Research Ethics of Erciyes University, Faculty of Medicine (2016/144). Written informed consent was obtained from the patients.

\section{Study Design}

In the cross-sectional study demographic data (age, gender), BMl, cause of hospitalization and hospital LOS were recorded. For the nutritional assessment, all patients were screened with NRS 2002 and SGA within the first days of admission to the patients. And also the edema and the acid were evaluated by the physician. The primary predictors of interest in our study were the NRS 2002 and SGA results of patients.

In the beginning, 168 patients were included to study but 34 patients did not complete the screening process by the reason of missing data and were excluded from the study. Finally, 134 patients completed the nutritional screening (Figure 1).

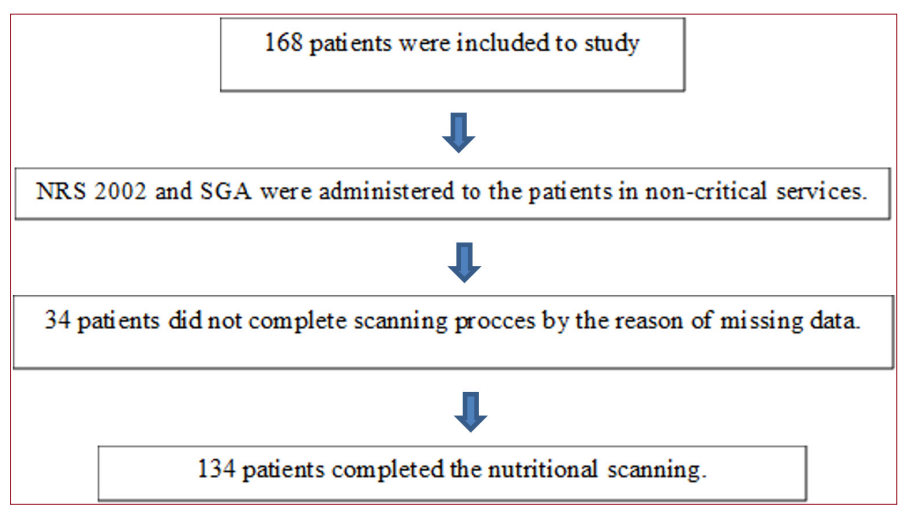

Figure 1. Study design 


\section{BMI Classification}

BMI as an objective measurement, refers to the weight for height, which is valid for both genders and all age groups. BMI classification according to WHO refers to, $<16.5 \mathrm{~kg} / \mathrm{m}^{2}$ severe malnourished, $18.5 \mathrm{~kg} / \mathrm{m}^{2}$ malnourished, $18.5-24.9$ $\mathrm{kg} / \mathrm{m}^{2}$ normal weight, $25-29.9 \mathrm{~kg} / \mathrm{m}^{2}$ overweight, $\geq 30 \mathrm{~kg} / \mathrm{m}^{2}$ obese in adults 9. ESPEN recognises malnutrition as, patient has (i) weight loss $>10-15 \%$ of body weight in last 6 months; (ii) $\mathrm{BMI}<18.5 \mathrm{~kg} / \mathrm{m}^{2}$; (iii) level $\mathrm{B}$ and C (mild-to-moderate and severe malnourished) Accordig to SGA or score $\geq 3$ according to NRS 2002; (iv) serum albumin $<30 \mathrm{~g} / \mathrm{L}$ (out of hepatic and renaldysfunction) 10 .

\section{Nutritional Status}

The nutritional status of all patients was screened both NRS 2002 and SGA within the first days of admission to the patients by a trained dietician.

The patients were classified as being nutritionally risk (NRS+): total score $\geq 3$ or nutritionally risk-free (NRS-): total score $<3$ according to NRS 2002 results.

The SGA screening normally provides three alternative categories for nutritional classification: well nourished (A); mild-to-moderately malnourished (B); or severely malnourished (C).

To facilitate the analysis of the influence of the nutritional status on the outcomes, to allow comparison with the NRS 2002 and SGA, patients were grouped as being either nonmalnourished $(A)$ or malnourished ( $B$ or $C$; included mildto-moderately malnourished and severely malnourished according to SGA results). In addition, according to the results of two screening tools, patients were grouped as being malnourished [included patients on (NRS+) or SGA (B or C)] and non-malnourished [included patients on (NRS-) or SGA (A)].

\section{Statistics}

Continuous variables were expressed as the mean and standard deviation. Statistical differences between groups were assessed using Chi-Square and Fisher exact tests for categorical variables, while the Student's t-test was used for continuous variables.

In order to analyze which variables affected the prevalence of malnutrition, a logistic regression analysis was performed, in which malnutrition according to the NRS 2002 and SGA was considered the dependent variable separately. The level of significance used was 0.05 . Statistical analysis was carried out with IBM SPSS Statistics 22.0.

\section{RESULTS}

\section{Nutritional Screening NRS 2002 and SGA Scores Frequencies}

A total of 134 adult patients ( 59 men $/ 75$ women) were included in to study with a mean age of $64.58 \pm 16.08$ years. Table 1 shows the results in terms of both nutritional screening tools. According to SGA, 86 (64.2\%) of the patients were classified as well nourished, 48 (35.8\%) were classified as malnourished (B or $\mathrm{C} ; 47$ of them were mild-to-moderately malnourished and 1 of them was severely malnourished). According to NRS 2002, $104(77.6 \%)$ were nutritional risk-free (or non-malnourished), $30(22.4 \%)$ of the patients were classified as nutritionally risk (or malnourished).

\begin{tabular}{|c|c|c|c|c|c|}
\hline \multirow{2}{*}{ Nutritional status } & \multicolumn{2}{|c|}{ NRS 2002} & \multicolumn{2}{|c|}{ SGA } & \multirow{2}{*}{$\mathbf{p}$} \\
\hline & $\mathbf{n}$ & $\%$ & $\mathbf{n}$ & $\%$ & \\
\hline Malnourished & 30 & 22.4 & 48 & 35.8 & \\
\hline Non-malnourished & 104 & 77.6 & 86 & 64.2 & $0.015^{*}$ \\
\hline Total & 134 & 100 & 134 & 100 & \\
\hline
\end{tabular}

The main data related to the nutritional status of patients in terms of both nutritional screening tools are shown in Table 2. Malnourished patients according to both nutritional screening tools have similar profiles in terms of gender and $\mathrm{BMI}$ to those of non-malnourished patients. There are different results in age profile of patients among tools. Although the mean the age of malnourished patients is similar with nonmalnourished patients according to SGA, the mean age of malnourished patients was higher than non-malnourished patients according to NRS $2002(74.83 \pm 12.50$ vs $61.63 \pm 15.82)$ and most of them (malnourished patients) are $\geq 65$ years ( 25 vs 5) $(p<0.001)$.

\section{BMI Classification and Nutritional Status}

In both screening tools most of the malnourished patients were overweight or obese (BMI $>25 \mathrm{~kg} / \mathrm{m}^{2}$ ) (the total overweight and obese patient rate $70 \%$ and $75 \%$ according to NRS 2002 and SGA; respectively) and only $6.7 \%$ of the malnourished patients, the BMI levels were below the $18.5 \mathrm{~kg} / \mathrm{m}^{2}$ ( $p>0.05$ ) (Table 2). According to SGA assessment weight loss in the last 6 months was higher in men than women $(3.97 \pm 5.85 \mathrm{~kg}$ and $2.16 \pm 3.66 \mathrm{~kg}$, respectively; $p=0.041$ ) (data not shown in table).

\section{Length of Hospital of Stay and Nutritional Status}

The hospital LOS (day) of malnourished patients and nonmalnourished patients according to NRS 2002 were similar. However, according to SGA screening the hospital LOS of malnourished patients was longer than non-malnourished patients $(17.90 \pm 16.93$ vs $10.79 \pm 11.23 ; p=0.004)$ (Table 3$)$.

\section{Factors Associated with Malnutrition}

A logistic regression analysis was performed, which considered malnutrition as a dependent variable and age, gender, BMI, hospital LOS (day) as independent variables. Only age was associated with malnourishment according to NRS 2002 (OR: 0.92; OR Cl: $0.88-0.96 ; \mathrm{p}<0.001)$ and only hospital LOS was associated with malnourishment according to SGA (OR:1.03; OR Cl: 1.00-1.06; $p<0.021$ ) (Table 4). 
Table 2. Main data related to the nutritional status

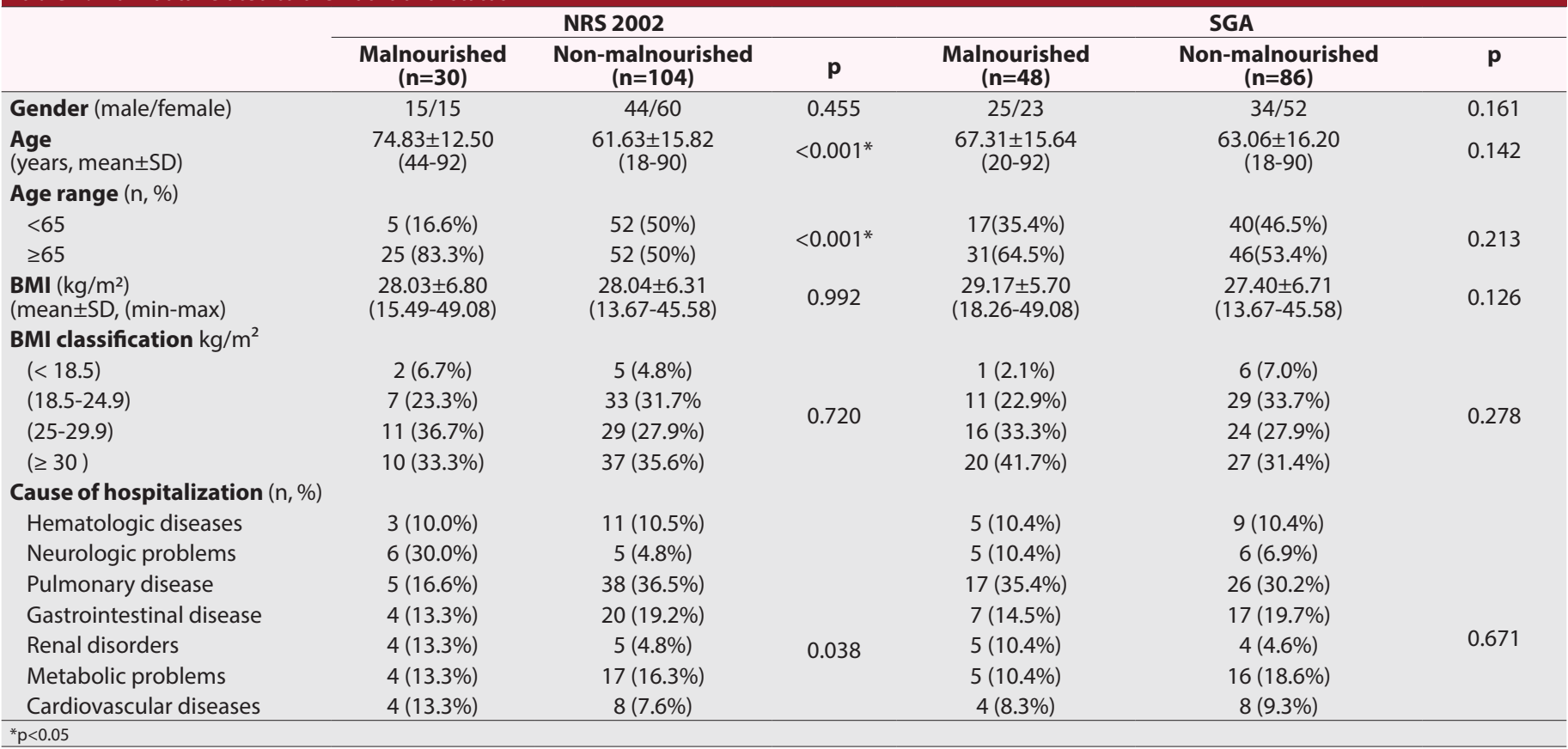

\section{Table 3. Length of hospital stay and the nutritional status with NRS 2002 or SGA}

\begin{tabular}{|c|c|c|c|c|c|c|}
\hline Hospital LOS (day) & \multicolumn{3}{|c|}{ NRS 2002} & \multicolumn{3}{|c|}{ SGA } \\
\hline $0-9$ day $(n, \%)$ & $13(16.7 \%)$ & $65(83.3 \%)$ & & $21(26.9 \%)$ & $57(73.1 \%)$ & \\
\hline 10-19 day & $9(25.7 \%)$ & $26(74.3 \%)$ & 0194 & $12(34.3 \%)$ & $23(65.7 \%)$ & ב בח * \\
\hline$\geq 30$ day & $4(40.0 \%)$ & $6(60.0 \%)$ & & $7(70.0 \%)$ & $3(30.0 \%)$ & \\
\hline
\end{tabular}

${ }^{*} \mathrm{p}<0.05$

Table 4. The factors of associated with malnutrition

\begin{tabular}{|c|c|c|c|c|c|c|}
\hline \multirow{2}{*}{ Variable } & \multicolumn{3}{|c|}{ Malnourished NRS 2002} & \multicolumn{3}{|c|}{ Malnourished SGA } \\
\hline & Odds Ratio (OR) & OR CI (\%95) & $\mathbf{p}$ & Odds Ratio (OR) & OR CI (\%95) & $\mathbf{p}$ \\
\hline Age & 0.92 & $0.88-0.96$ & $<0.001^{*}$ & 1.01 & $0.99-1.04$ & 0.220 \\
\hline Gender (male) & 0.92 & $0.37-2.29$ & 0.871 & 1.38 & $0.65-2.93$ & 0.397 \\
\hline BMI & 1.01 & $0.95-1.09$ & 0.592 & 1.03 & $0.97-1.09$ & 0.248 \\
\hline Hospital LOS (day) & 0.97 & $0.94-1.00$ & 0.099 & 1.03 & $1.00-1.06$ & $0.021^{*}$ \\
\hline
\end{tabular}

\section{DISCUSSION}

Screening the nutritional status of hospitalized patients, in the beginning, provides positive results on patients outcomes and on avoiding comorbidities. Malnutrition is a well-known factor that increases the length of stay in hospital, morbidity and morbidty. ${ }^{[2]}$ Determination of nutritional status helps physicians and clinical nutritionists to decide on the best regimen which should be prescribed for a patient. ${ }^{[11]}$ Although many nutritional screening tools have been developed, there is no screening tool considered to be the best standard for defining nutritional risk. Most methods are cumbersome and time-consuming and therefore not performed on a routine basis. NRS 2002 is the most commonly used screening method in hospitalized patients and ESPEN recommends the NRS 2002 for nutritional assessment. Patients are evaluated and scored for malnutrition and disease severity in NRS 2002 to take into consideration the patient's nutrition risk at the time of assessment and used to identify hospitalized patients who may benefit from nutrition support. It is relatively easy to calculate and does not require a significant amount of time or data points. ${ }^{[12]}$ SGA is also a simple and effective screening tool which has been developed to evaluate the physiological symptoms observed in functional capacity and malnutrition or the conditions involved in malnutrition. Different from NRS 2002, subjective parameters are used in the assessment. Screening tools contain different objective and subjective parameters and this may lead to determine malnutrition rates at different levels. Therefore, there are many studies comparing these screening tests in the literature and they also found different malnutrition rates among tools. In a cohort study, 7973 adult patients from 47 hospitals scanned 
to determining nutritional status and the rate of malnourished patients was found $36.9 \%$ by NRS 2002 and $44.9 \%$ by SGA. ${ }^{[13]}$ Fernández et al. ${ }^{[14]}$ found malnutrition rate $35.8 \%$ according to NRS 2002 and $62.1 \%$ according to SGA in hospitalized patients. Konturek et al. ${ }^{[15]}$ scanned 815 hospitalized patients and found a malnutriton rate of $44.6 \%$ according to NRS 2002 and 44.6 $\%$ according to SGA. In a study conducted by Olivares et al..16] $21.3 \%$ of the hospitalized patients were malnourished according to NRS 2002; and $19.5 \%$ of the patients were malnourished according to SGA. Raslan et al. ${ }^{[17]}$ conducted a study with the aim of evaluating the ability of NRS 2002 and SGA to predict malnutrition related to poor clinical outcomes. They found that of the patients screened, $27.9 \%$ were at nutritional risk (NRS+) and $38.9 \%$ were malnourished (SGA B or C). In the current study, we found that malnutrition rates were $22.4 \%$ according to NRS 2002 and $35.8 \%$ according to SGA. Consistent with most of the other study results, in our study; the rate of malnourished patients among NRS 2002 was lower than among SGA. This result may be related to subjective parameters included in SGA. Because objective and subjective parameters alone have some limitations on determining nutritional status, it is recommended that objective and subjective parameters should be used together for a comprehensive nutritional assessment. ${ }^{[7]}$ Among objective parameters, anthropometric measurements, are effective in the diagnosis of malnutrition. BMI is one of the most commonly used anthropometric measurements in the clinic but it is not sufficient alone to determine malnutrition. Malnutrition is also detected at a normal weight or even in overweight patients. There are also studies reporting that the BMI of malnourished patients is higher than the BMI of non-malnourished patients. In a study conducted by Borek et al. ${ }^{[18]} 292$ patients with renal disorders in Poland, were screened by using NRS 2002 and SGD methods, they found that $38 \%$ of the patients determined on nutritional risk were weighted or obese and only $8.4 \%$ of the patients with $\mathrm{BMI}$ below $18.5 \mathrm{~kg} / \mathrm{m}^{2}$ at risk of malnutrition. In the University Hospital of Haukeland Norway, 3279 patients were screened by using NRS 2002, 12\% of overweight patients and $11 \%$ of obese patients were found on nutritional risk. ${ }^{[19]}$ In the current study, we found that among NRS 2002 screening, malnourished patients $36.7 \%$ of them were overweight and $33.3 \%$ were obese. These rates for SGA screening, were 33.3\% and $41.7 \%$ for overweight and for obese, respectively. All these results show that weigh status and $\mathrm{BMl}$ of the patients, as a single parameter, did not alone reflect completely the nutritional status and malnutrition risk of hospitalzed patients.

Age, prolonged hospital stay and increased complications are among the independent risk factors of malnutrition. The prevelence of malnutrition is 5 times higher in patients over 80 years of age than in patients under 50 years of age. ${ }^{[20]}$ Raslan et al. ${ }^{[21]}$ screened hospitalized patients with NRS 2002 and detected malnutrition prevelance $42 \%$ in elderly patients ( $>65 \mathrm{y}$ old), and $27.9 \%$ in all patients. In a study, malnutrition was found $53 \%$ of patients over the age of 64 according to SGA screening and $46 \%$ according to NRS 2002 screening. ${ }^{[22]}$ In our study, according to NRS 2002 results, the rate of malnourished patients was found $8.8 \%$ of the patients aged $<65$ years and $32.5 \%$ of the patients aged $\geq 65$ years $(<0.001)$. In SGA results, the rate of malnourished patients was found $29.8 \%$ of the patients aged $<65$ years and $40.3 \%$ of the patients aged $\geq 65$ years $(p>0.05)$.

Length of hospital stay is an important independent factor affecting malnutrition. A prolonged length of hospital stay is related to deterioration of the nutritional status of patients and increased malnutrition rates. Previous studies have shown the impact of nutritional status on LOS. ${ }^{[15,23,24]}$ In a study conducted in Spain with the aim of assessing the nutritional risk of hospitalized patients using SGA, found a significantly relationship between nutritional risk and length of hospital stay. Correia et al. ${ }^{[23]}$ demonstrate that malnourished patients had significantly longer length of hospital stay than well nourished patients ( $16.77 \pm 24.5$ days and $10.17 \pm 11.7$ days, respectively). In a study conducted by Velasco et al. ${ }^{[25]}$ according to the NRS 2002 screening, the mean length of hospital stay was $8.9 \pm 7.9$ days in patients without risk of malnutrition and $13.7 \pm 9.5$ days in patients with risk of malnutrition and according to SGA screening, it was found to be $8.8 \pm 7.7$ days in nonmalnourished patients and $13.7 \pm 9.7$ days in malnourished patients. Olveira et al. ${ }^{[24]}$ conducted a multicenter prospective study, they scanned patients by SGA and found that the mean duration of hospital stay was $30.9 \pm 28.3$ days for malnourished patients and $37.3 \pm 27.2$ days for malnourished patients. In a study conducted by Konturekt et al. ${ }^{[15]}$ it was found that the length of hospital stay was significantly shorter in the well-fed patients (4.0 \pm 4.2 days) compared to the malnourished patients (7.8 \pm 7.7 days) according to the NRS 2002 screening. We found that the hospital LOS (day) of malnourished patients and nonmalnourished patients according to NRS 2002 screening were similar. But according to SGA screening the hospital LOS of malnourished patients was longer than non-malnourished patients ( $17.90 \pm 16.93$ vs $10.79 \pm 11.23)(p=0.004)$. And in patients with the hospital, LOS is more than 30 days, $40 \%$ of them were malnourished according to NRS 2002 results and $70 \%$ of them were malnourished according to SGA results. In our present study, hospital LOS was associated with malnourishment according to SGA. This result gives a supportive finding that prolonged length of hospital stay increases malnutrition risk in hospitalized patients.

\section{Study Limitations}

The main limitation of this study was the group of patients was heterogeneous and have a different cause of hospitalization. There are so many previous studies accessing the nutritional status of patients in intensive care units. However, we studied with patients among the different causes of hospitalization with the aim of assessing patients' nutrition status in all hospitalized patients in different clinics. Another limitation could be related to the impact of malnutrition on the outcomes. The results for readmission rates and mortality could not be followed up which were evaluated in some other studies related to nutritional screening. 


\section{CONCLUSION}

Our study showed that SGA identified higher rates of malnourished patients than NRS 2002. Screening tools have different characteristics and capabilities in detecting malnutrition. The NRS 2002, as an objective, remarkably powerful and modern instrument that was developed for hospital settings and is recommended by the European Society of Parenteral and Enteral Nutrition, seems to provide a better yield for an objective assessment. Besides this, adding subjective parameters to the assessment could increase the capability of detecting nutrition risk of hospitalized patients. Applying objective and subjective parameters together in nutritional evaluation provides positive results for a comprehensive nutritional assessment. Althought these different results of the screeing tools, nutrional risk or malnutrition should be detect as early as possible in all hospitalized patients to avoid possible outcomes of malnutrition.

\section{ETHICAL DECLARATIONS}

Ethics Committee Approval: The study was carried out with the permission of Clinical Research Ethics Committee of Erciyes University, Faculty of Medicine (2016/144).

Informed Consent: Written informed consent was obtained from the patients.

Referee Evaluation Process: Externally peer-reviewed.

Conflict of Interest Statement: The authors have no conflicts of interest to declare.

Financial Disclosure: The authors declared that this study has received no financial support.

Author Contributions: All of the authors declare that they have all participated in the design, execution, and analysis of the paper, and that they have approved the final version.

Acknowledgment: Thank for the health care profeessionals of Malatya Training and Research Hospital. This study would not have been possible without the support of all our patients.

\section{REFERENCES}

1. Norman K, Pichard C, Lochs H, Pirlich M. Prognostic impact of diseaserelated malnutrition. Clin Nutr 2008;27(1):5-15.

2. Planas $M$, Audivert $S$, Pérez-Portabella $C$, et al. Nutritional status among adult patients admitted to an university-affiliated hospital in Spain at the time of genoma. Clin Nutr 2004;23(5):1016-24.

3. Wooley JA. American Dietetic Association endorses A.S.P.E.N. enteral nutrition practice recommendations. J Am Diet Assoc 2010;110(5):683-5.

4. McClave SA, Taylor BE, Martindale RG, et al. Society of Critical Care Medicine; American Society for Parenteral and Enteral Nutrition. Guidelines for the Provision and Assessment of Nutrition Support Therapy in the Adult Critically III Patient: Society of Critical Care Medicine (SCCM) and American Society for Parenteral and Enteral Nutrition (A.S.P.E.N.). J Parenter Enteral Nutr 2016;40(2):159-211.

5. Kondrup J, Allison SP, Elia M, Vellas B, Plauth M. Educational and Clinical Practice Committee, European Society of Parenteral and Enteral Nutrition (ESPEN). ESPEN guidelines for nutrition screening 2002. Clin Nutr $2003 ; 22(4): 415-21$.
6. Field LB, Hand RK. Differentiating malnutrition screening and assessment: a nutrition care process perspective. J Acad Nutr Diet 2015;115(5):824-8.

7. Sungurtekin $H$, Sungurtekin $U$, Oner $O$, Okke D. Nutrition assessment in critically ill patients. Nutr Clin Pract 2008;23(6):635-41.

8. Gultekin A, Memis D, Inal MT, Uzundere O, Turan FN. The impact of nutritional risk screening 2002 and subjective global assessment upon prognosis for intensive care patients Prog Nutr 2016; 18(1):47-5.

9. Weir CB, Jan A. BMI Classification Percentile And Cut Off Points. In: StatPearls. Treasure Island (FL): StatPearls Publishing; June 29, 2021.

10. Cederholm T, Barazzoni R, Austin P, et al. ESPEN guidelines on definitions and terminology of clinical nutrition. Clin Nutr 2017;36(1):49-64.

11. Javid Mishamandani Z, Norouzy A, Hashemian SM, et al. Nutritional status of patients hospitalized in the intensive care unit: A comprehensive report from Iranian hospitals, 2018. J Crit Care 2019;54:151-158.

12. Canales C, Elsayes A, Yeh DD et al. Nutrition Risk in Critically III Versus the Nutritional Risk Screening 2002: Are They Comparable for Assessing Risk of Malnutrition in Critically III Patients? J Parenter Enteral Nutr 2019:43(1):8187.

13. Pineda JCC, Gómez García A, Velasco N, Graf JIDP, Adámes AM, Torre AM. Nutritional assessment of hospitalized patients in Latin America: association with prognostic variables. The ENHOLA study. Nutr Hosp 2016; 33(3):655-62.

14. Fernández AC, Casariego AV, Rodríguez IC Pomar MDB. Eficaciay efectividad de las distintas herramientas de cribado nutricional en un hospital de tercer nivel. Nutr Hosp 2015;31:2240-6.

15. Konturek PC, Herrmann HJ, Schink K, Neurath MF, Zopf Y. Malnutrition in Hospitals: It Was, Is Now, and Must Not Remain a Problem! Med Sci Monit 2015;21:2969-75

16. Olivares J, Ayala L, Salas-Salvadó J, et al. Assessment of risk factors and test performance on malnutrition prevalence at admission using four different screening tools. Nutr Hosp 2014;29:674-80.

17. Raslan M, Gonzalez MC, Torrinhas RS, Ravacci GR, Pereira JC, Waitzberg DL. Complementarity of Subjective Global Assessment (SGA) and Nutritional Risk Screening 2002 (NRS 2002) for predicting poor clinical outcomes in hospitalized patients. Clin Nutr 2011;30(1):49-53.

18. Borek P, Chmielewski M, Małgorzewicz S, Slizie'n DA. Analysis of outcomes of the NRS 2002 in patients hospitalized in nephrology wards. Nutrients 2017;9:287.

19. Tangvik RJ, Tell GS, Guttormsen $A B$, et al. Nutritional risk profile in a university hospital population. Clin Nutr 2015;34(4):705-11.

20. Kandiah J, Stinnett L, Lutton D. Visual plate waste in hospitalized patients: length of stay and diet order. J Am Diet Assoc 2006;106(10):1663-6.

21. Raslan M, Gonzalez MC, Dias MC, et al. Comparison of nutritional risk screening tools for predicting clinical outcomes in hospitalized patients. Nutrition 2010;26(7-8):721-6.

22. Ozkalkanli MY, Ozkalkanli DT, Katircioglu K, Savaci S. Comparison of tools for nutrition assessment and screening for predicting the development of complications in orthopedic surgery. Nutr Clin Pract 2009;24(2):274-80.

23. Correia MI, Campos AC; ELAN Cooperative Study. Prevalence of hospital malnutrition in Latin America: the multicenter ELAN study. Nutrition 2003t; 19(10):823-5.

24. Olveira G, Tapia JM, Ocón J, et al. Study Group of Hyperglycemia in Parenteral Nutrition; Nutrition Area of the Spanish Society of Endocrinology and Nutrition (SEEN). The subjective global assessment predicts in-hospital mortality better than other nutrition-related risk indexes in noncritically ill inpatients who receive total parenteral nutrition in Spain (prospective multicenter study). J Acad Nutr Diet 2013;113(9):1209-18.

25. Velasco C, García E, Rodríguez V et al. Comparison of four nutritional screening tools to detect nutritional risk in hospitalized patients: a multicentre study. Eur J Clin Nutr 2011;65(2):269-74. 